\title{
PENGARUH DEKLINASI MATAHARI TERHADAP PARAMETER CUACA WILAYAH MALANG DAN SEKITARNYA
}

\author{
Achmad Sasmito ${ }^{1}$, Alfan S. Praja ${ }^{1 *}$, Linda F. Muzayanah ${ }^{2}$ dan Rahayu S.S. \\ Sudewi \\ ${ }^{1}$ Pusat Penelitian dan Pengembangan BMKG \\ ${ }^{2}$ Stasiun Klimatologi Malang BMKG \\ *alfan.sukmana@gmail.com
}

Received 29-09-2020, Revised 03-08-2021, Accepted 21-08-2021, Published 01-10-2021

\begin{abstract}
Cold temperatures occur in the Dieng and Lumajang highlands from the end of July to August 2020. At almost the same time, hot temperatures also occur in the United States, Japan, and Spain. This study discusses the effect of declination of the sun on weather parameters in Malang and its surroundings. Besides, it also discusses a physical and dynamic review of the occurrence of hot air temperatures in the northern hemisphere (BBU) with cold temperatures in the southern hemisphere (BBS). The data used are numerical data of solar radiation of the atmosphere and observation data from AWS which includes elements of global radiation, temperature, and surface air humidity. Data samples were taken from Malang Climatology Station and Karang Kates Geophysical Station which represent BBS and weather information from BBU. Estimation of cold temperatures in Ranu Pani, Lumajang was carried out using the lapse rate model. Cold temperatures that occur in the East Java region are influenced by the declination of the Sun, solar radiation, the transmissivity coefficient, and the temperature advection process from Australia. When the sun is in the north, there are cold temperatures in the southern part of the earth and vice versa. The occurrence of hot or cold temperatures in each region is also influenced by the composition of gases in the atmosphere, geography, topography, and the influence of advection due to the influence of the surrounding air.
\end{abstract}

Keywords: cold temperature; declination of the sun; solar radiation; lapse rate model; advection

\section{ABSTRAK}

Suhu udara dingin terjadi di dataran tinggi Dieng dan Lumajang pada akhir Juli hingga Agustus 2020. Pada saat yang hampir bersamaan, suhu udara panas terjadi pula di Amerika Serikat, Jepang, dan Spanyol. Penelitian ini membahas pengaruh deklinasi matahari terhadap parameter cuaca di Malang dan sekitarnya. Selain itu, dibahas juga tinjauan fisis dan dinamis terjadinya suhu udara panas di Bumi bagian utara (BBU) dengan suhu udara dingin di bumi bagian selatan (BBS). Data yang digunakan yaitu data numerik radiasi matahari di atmosfer dan data observasi dari AWS yang meliputi unsur radiasi global, suhu, dan kelembapan udara permukaan. Sampel data diambil dari stasiun Klimatologi Malang dan Stasiun Geofisika Karang Kates yang mewakili BBS dan informasi cuaca dari BBU. Estimasi suhu dingin di Ranu Pani, Lumajang dilakukan dengan menggunakan model lapserate. Suhu dingin yang terjadi di wilayah jawa timur dipengaruhi oleh deklinasi matahari, radiasi matahari, koefisien transmisivitas dan proses adveksi suhu dari Australia. Saat matahari berada di utara, terjadi suhu dingin di bumi bagian selatan dan sebaliknya. Terjadinya suhu panas atau dingin di setiap wilayah dipengaruhi juga oleh komposisi gas di atmosfer, geografi, topografi, dan pengaruh adveksi karena pengaruh udara di sekitarnya.

Kata kunci: suhu dingin; deklinasi matahari; radiasi matahari; model lapse rate; adveksi 


\section{PENDAHULUAN}

Pada bulan Juni sampai dengan Agustus 2020, suhu udara dingin telah terjadi di beberapa wilayah Indonesia pada bumi bagian selatan (BBS) khususnya di daerah dataran tinggi. Suhu udara di komplek Candi Arjuna pegunungan Dieng Jawa Tengah (elevasi 2579 meter) tanggal 25 juni 2018 tercatat dibawah nol (o) dan tanggal 24 Juni 2019 suhu udara tercatat $-9^{\circ} \mathrm{C}^{[1]}$. Fenomena tersebut berulang pada tanggal 24 sampai dengan 27 Juli 2020 , dengan suhu udara tercatat $3^{\circ}$ hingga $7^{\circ} \mathrm{C}^{[2]}$, sedangkan di Taman Nasional Bromo Tengger Semeru (TNBTS) elevasi 2329 meter, pada tanggal 29 Juni 2019 tercatat $3^{\circ} \mathrm{C}$ dan pada tanggal 26 Juli 2020 suhu udara mencapai $-3^{\circ} \mathrm{C}$, sementara pada tanggal 30 Juli 2020 tercatat suhu udara tercatat $-2^{\circ} \mathrm{C}$ di desa Ranu Pani, Senduro Lumajang elevasi 2114 $\operatorname{meter}^{[3]}$.

Sebaliknya kondisi cuaca di Bumi Bagian Utara (BBU) mengalami suhu sangat panas. Badan Cuaca Nasional Spanyol, Aemet mencatat suhu udara hingga $42^{\circ}$ Celcius (107 derajat Fahrenheit) pada tanggal 31 Juli 2020, di pantai utara San Sebastian. Kota Palma, di pulau Mediterania Spanyol di Mallorca, mencatat rekor 40,6 $6^{\circ}$ Celcius, sementara itu Aemet mengungkapkan di waktu malam hari, suhu udara turun mencapai 20 derajat Celcius. Berdasarkan data klimatologi kondisi tersebut sering terjadi di banyak bagian Spanyol pada bulan Juli ${ }^{[4]}$. Sementara itu Badan Cuaca Nasional Inggris, MET Office dalam keterangannya menjadikan hari Jumat (31 juli 2020) sebagai hari terpanas, rekor terpanas ketiga terjadi di Bandara Heathrow barat London, banyak warga Inggris di utara mencari tempat teduh karena suhu naik diatas 37 derajat Celcius.

Pada saat terjadi cuaca panas yang ekstrim di belahan bumi bagian utara (BBU) seperti yang terjadi di Jepang 17 Agustus 2020 suhu mencapai $41^{\circ} \mathrm{C}^{[5]}$, di wilayah Los Angeles pada tanggal 14 Agustus 2020 suhu ekstrim siang hari tercatat $52^{\circ} \mathrm{C}^{[6]}$ sebaliknya dimalam hari tercatat $21^{\circ} \mathrm{C}$, bahkan di California di taman Death Valley pada tanggal 18 agustus 2020 suhu maksimum tercatat $54,4^{\circ} \mathrm{C}$ di klaim sebagai suhu udara permukaan terpanas dalam seabad $^{[7]}$, sebaliknya wilayah Indonesia yang posisinya sebagian besar berada di BBS pada bulan Juli akan mengalami suhu udara relatif dingin dibandingkan bulan Januari. Memperhatikan fenomena suhu udara panas di BBU pada siang hari dan sebaliknya suhu udara dingin di malam hari (BBS) akan berlangsung setiap tahun, hanya saja variasinya berbeda dari tahun ketahun, hal ini berkaitan erat dengan komposisi gas di sepanjang medium penjalaran radiasi matahari tersebut (atmosfer).

Jika ditinjau dari kerapatannya (density) komposisi bumi terdiri dari tiga komponen yaitu daratan, lautan dan udara yang disebut atmosfer. Atmosfer dari permukaan bumi sampai puncak atmosfer mengandung berbagai macam gas pada berbagai elevasi yang sangat berperan penting dalam memfilter radiasi gelombang elektromagnetik dari Matahari. Besarnya intensitas radiasi matahari yang diterima di permukaan bumi (Hs) dipengaruhi oleh radiasi di puncak atmosfer (extraterestrial solar radiation $/ \mathrm{Ho})^{[8,9]}$, medium sepanjang penjalaran atmosfer yang mengandung berbagai jenis gas di atmosfer, kondisi bidang penerima dipermukaan bumi miring/datar ${ }^{[10]}$, dan jenis media bidang penerima daratan atau lautan ${ }^{[11]}$. Radiasi puncak atmosfer merupakan radiasi awal sebelum melalui medium atmosfer. Setelah radiasi matahari sampai di permukaan bumi sebagian diserap bumi dan dipancarkan kembali ke atmosfer berupa radiasi gelombang panjang (Outgoing Long-wave Radiation/OLR) yang berubah menjadi sumber energi panas yang menyatakan ukuran suhu suatu zat di permukaan bumi sampai puncak troposfer.

Terjadinya fenomena suhu udara dingin pada musim kemarau di wilayah dataran tinggi Indonesia dan kaitannya dengan suhu udara di belahan bumi utara merupakan fenomena 
meteorologi yang penting untuk diteliti. Untuk menelusuri terjadinya suhu udara panas atau dingin di berbagai negara tersebut akan dijelaskan berdasarkan tinjauan fisis dan dinamis yang didukung data iklim dan cuaca. Besarnya radiasi matahari yang sampai di permukaan bumi dipengaruhi oleh komposisi gas di atmosfer dan dipengaruhi posisi deklinasi matahari arah utara-selatan dalam setahun dimana lintasan terjauh mencapai 23,5 LU/LS. Selanjutnya, akan diteliti pula pengaruh deklinasi matahari terhadap suhu, kelembapan, tekanan, dan parameter cuaca lainnya di wilayah Malang dan sekitarnya.

\section{METODE}

Data yang digunakan pada penelitian ini adalah data dari pengamatan alat Automatic Weather Station (AWS) BMKG meliputi data radiasi matahari dipermukaan bumi (Hs), suhu dan kelembaban udara permukaan periode 2015-2020 Staklim Malang koordinat 7,9 ${ }^{\circ}$ LS; $112.5^{\circ}$ BT dengan elevasi 600 meter dan Data AWS Stasiun Geofisika Karangkates, koordinat $8,15^{\circ} \mathrm{LS} ; 112,45^{\circ}$ BT dengan elevasi 325 meter, pada 2 Agustus 2020 yang posisinya mewakili wilayah BBS. Analisis juga dilakukan pada data radiasi puncak atmosfer (Ho) di beberapa negara di BBU seperti pada Gambar 1 yaitu Tokyo $\left(35,7^{\circ} \mathrm{LU}\right.$; $139,4^{\circ} \mathrm{BT}$ ), Madrid (40,4 $4^{\circ} \mathrm{LU} ; 3,7^{\circ} \mathrm{BB}$, dan Los Angeles-USA ( $34^{\circ} \mathrm{LU} ; 118,3^{\circ} \mathrm{BB}$ ), kemudian dijelaskan berdasarkan tinjauan fisis dan dinamisnya. Disamping itu juga digunakan analisis data suhu minimum pada bulan januari dan bulan juli 2020 wilayah Australia yang diperoleh dari situs bom.gov.au.

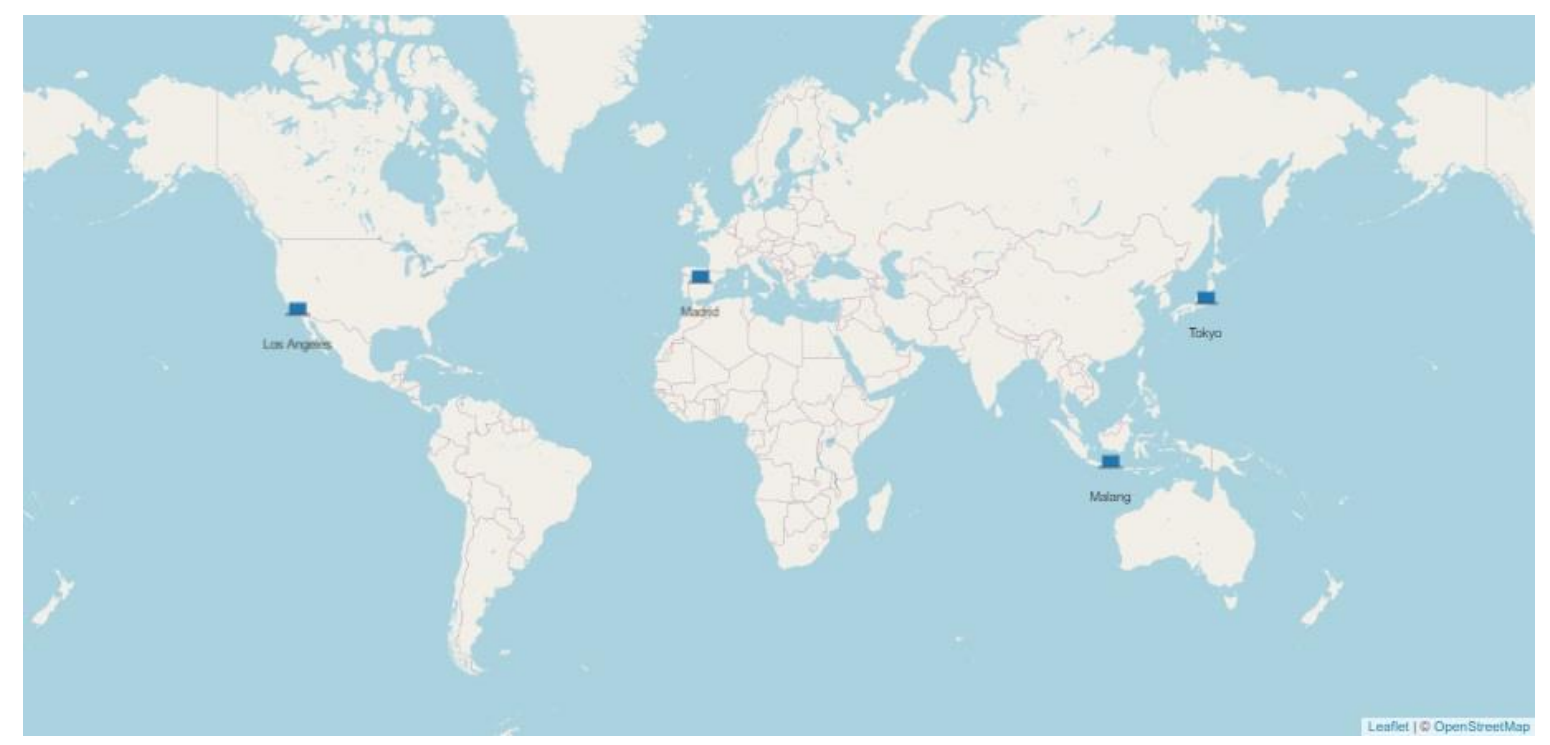

Gambar 1. Lokasi penelitian yang mewakili BBU dan BBS

Besarnya radiasi Ho yang dihitung secara numeric sebagai fungsi koordinat stasiun, menggunakan persamaan berikut

$$
\text { Ho = 24/P.Io.(1+0.033. }(\cos (2 P \cdot n / 365,24) \cdot \cos (q) \cdot \cos (d) * \sin (\sin W s-W s \cdot \cos W S)))
$$

Dengan Ho radiasi di puncak atmosfer ( cal/cm2/hari), d= deklinasi matahari (derajat), Ws = panjang hari $(\mathrm{jam}), \mathrm{Io}=$ Solar constant $(1353$ watt $/ \mathrm{m} 2), \mathrm{q}=$ lintang stasiun (derajat), $\mathrm{N}=$ hari ke $n(\operatorname{tgl} 1$ Januari, $n=1), d=(23+27 / 60) \cdot \sin (360 \cdot n / 365,24)$, dan WS $=\operatorname{arcos}(-\operatorname{tg}$ q.tg d) ${ }^{[12]}$.

Besarnya radiasi yang sampai di permukaan bumi dipengaruhi oleh komposisi gas di atmosfer sehingga dapat diketahui nilai koeffisien transmisivitas. Koefisien transmisivitas 
dihitung sebagai perbandingan nilai $\mathrm{Hs} / \mathrm{Ho}^{*} 100 \%{ }^{[13]}$. Semakin besar koefisien transmisivitas, semakin kecil hambatan penjalaran radiasi matahari di atmosfer.

Perhitungan laju perubahan suhu terhadap ketinggian (arah vertical) menggunakan formula model lapse rate. Laju perubahan suhu udara kering sebesar 9,8/km ${ }^{[14]}$, sedangkan untuk perubahan suhu udara basah umumnya sebesar $6,5 / \mathrm{km}^{[15,16]}$. Nilai tersebut bervariasi untuk Tmean, Tmin dan Tmax masing-masing sebesar $6.9{ }^{\circ} \mathrm{C} / \mathrm{km}, 5.5{ }^{\circ} \mathrm{C} / \mathrm{km}$ dan 8.8 ${ }^{\circ} \mathrm{C} / \mathrm{km}^{[17]}$. Lapisan atmosfer yang menjadi batas antara gas dan uap berada pada ketinggian yang disebut lifting condensation level (LCL) ${ }^{[18]}$. Sedangkan lapisan atmosfer yang menjadi batas wujud perubahan uap dan bintik-bintik air disebut lapisan convective condensation level (CCL) atau lazim disebut tinggi dasar awan. Untuk mengetahui lapisan LCL dan CCL dapat diestimasi bila diketahui data suhu udara permukaan dan suhu dew point dengan model lapserate. Secara sederhana dapat dijelaskan seperti Gambar 2 berikut ini:
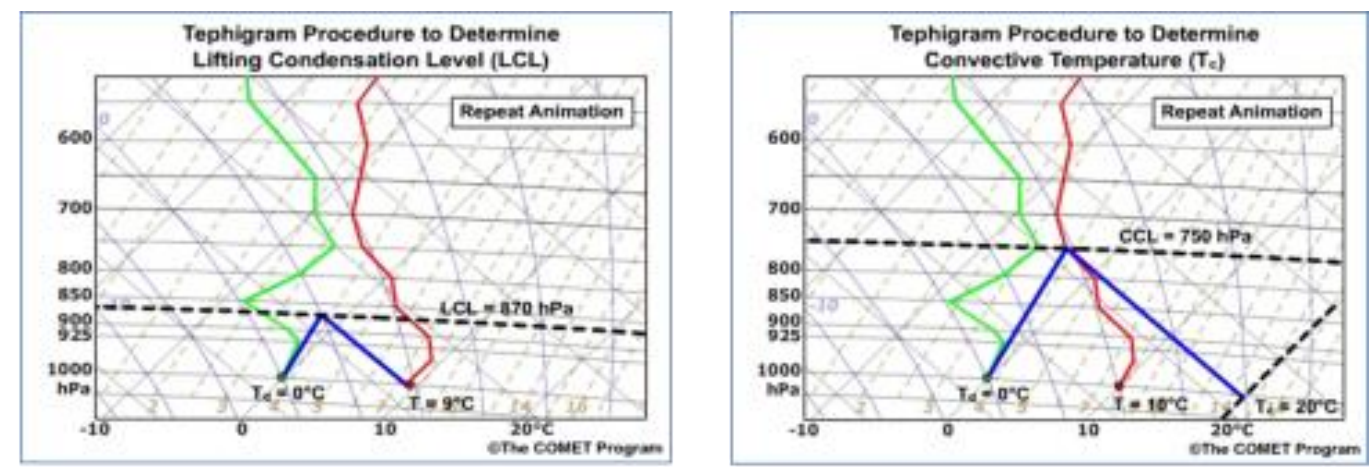

Gambar 2. Tehnis menghitung tinggi lapisan konvektif dan dasar awan dari data Suhu (T) dan Suhu titik embun $(\mathrm{Td})$ permukaan

Dengan asumsi atmosfer sebagai gas ideal, perhitungan tinggi lapisan LCL dan CCL dengan menggunakan formula $\mathrm{H}_{\mathrm{lcl}}=125 *(\mathrm{~T}-\mathrm{Td})$ dan $\mathrm{H}_{\mathrm{ccl}}=217,7 *(\mathrm{~T}-\mathrm{Td})$. Dimana $\mathrm{T}$ adalah Suhu udara permukaan dan Td Suhu udara dew point permukaan ${ }^{[18,19]}$.

\section{HASIL DAN PEMBAHASAN}

Wilayah Indonesia yang sebagian berada di BBS umumnya memiliki tipe iklim monsoon, berdasarkan data klimatologi pada pertengahan tahun berlangsung musim kemarau. Pada saat musim kemarau, suhu udara siang hari dirasakan oleh tubuh kita terasa panas, sebaliknya pada malam hari suhu udara dirasakan sangat dingin. Hal ini dikarenakan pada siang hari bumi menyerap panas sedangkan pada malam hari bumi melepas panas sehingga terasa dingin. Hasil pengamatan data AWS stasiun Geofisika Karang Kates, Kabupaten alang, Jawa Timur elevasi 325 meter dari permukaan laut (Gambar 3) menunjukkan pada siang hari sekitar pukul 13.00 WIB suhu maksimum mencapai $30^{\circ} \mathrm{C}$, sedang di malam hari menjelang pagi hari suhu minimum tercatat $18^{\circ} \mathrm{C}$. Berdasarkan rekaman data tersebut tampak adanya rentang suhu yang cukup besar mencapai $12^{\circ} \mathrm{C}$ dalam satu hari pengamatan. Terjadinya suhu udara yang cukup dingin tersebut berkaitan dengan kandungan uap air di udara relatif sedikit sehingga pancaran radiasi gelombang panjang dari bumi lolos ke atmosfer tanpa adanya hambatan gas di udara (uap air dan gas lainnya), keadaan tersebut mengakibatkan suhu udara terasa dingin. 


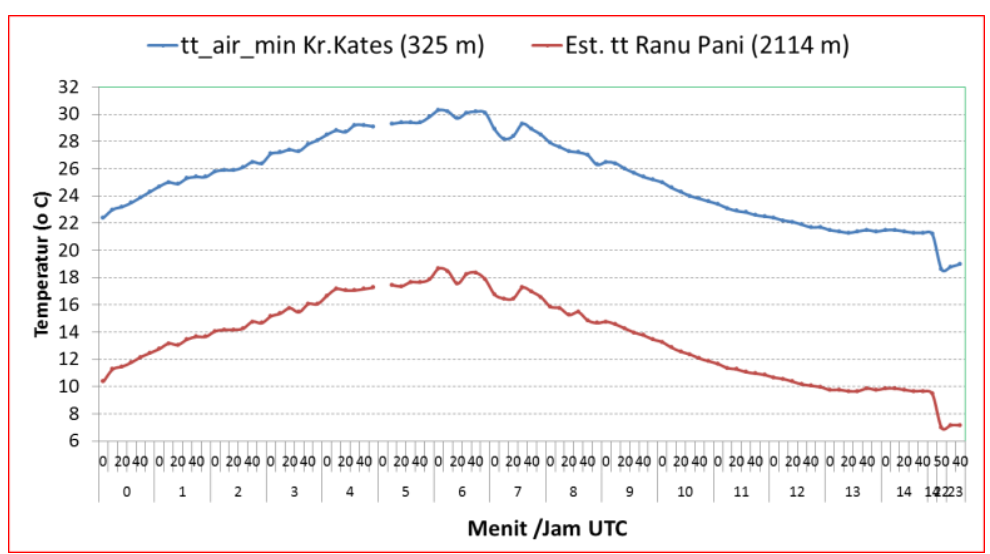

Gambar 3. Distribusi Suhu udara minimum tiap 10 menit Stasiun Karangkates (biru) dan estimasi Suhu udara Minimum di Ranu Pani Senduro Lumajang (merah)

Dari berbagai media menginformasikan bahwa di daerah Ranu Pani Senduro Lumajang (elevasi $2144 \mathrm{~m}$ ) dilaporkan suhu udara tanggal 30 juli 2020 mencapai $-2^{\circ} \mathrm{C}$ karena tidak ada stasiun BMKG di daerah tersebut, maka untuk menguji informasi tersebut dilakukan analisis dengan menggunakan data suhu udara permukaan stasiun geofisika Karangkates ($8,2^{\circ} \mathrm{LS}, 112,7^{\circ} \mathrm{BT}$, elevasi 325 meter) pada tanggal 2 Agustus 2020. Dipilihnya tanggal tersebut karena ketersediaan data yang ada. Setelah dilakukan transformasi dengan menggunakan model lapse rate, diperoleh suhu udara minimum permukaan di daerah Ranu Pani mencapai $7,2^{\circ} \mathrm{C}$ (Gambar 3). Dari gambar tersebut tampak gambar terputus karena data temperatur pada pukul 05.00 UTC tidak terekam pada alat AWS karena kendala teknis.

Bumi terdiri dari $1 / 3$ berupa daratan, $2 / 3$ berupa lautan, dan diatas daratan dan lautan bumi berupa atmosfer. Perbandingan keadaan bumi di BBU dengan BBS tampak bahwa daratan relatif lebih luas berada di BBU wilayahnya yaitu sekitar $2 / 3$ bagian dan $1 / 3$ bagian berada di BBS, sebaliknya di BBS lautan justru lebih luasnya yaitu sekitar $2 / 3$ bagian, sedang $1 / 3$ bagian. Kondisi geografis yang berbeda ini mengakibatkan respon radiasi matahari yang diterima di permukaan bumi pada arah potongan melintang akan berbeda pada BBS dan BBU keadaan tersebut membangkitkan sirkulasi arah utara-selatan yang lazim disebut sirkulasi Hadley. Demikian juga bila ditinjau dari arah timur barat, wilayah Indonesia merupakan Maritim kontinental dibandingkan dengan di lautan Pasifik dan Hindia sehingga menimbulkan sirkulasi walker.

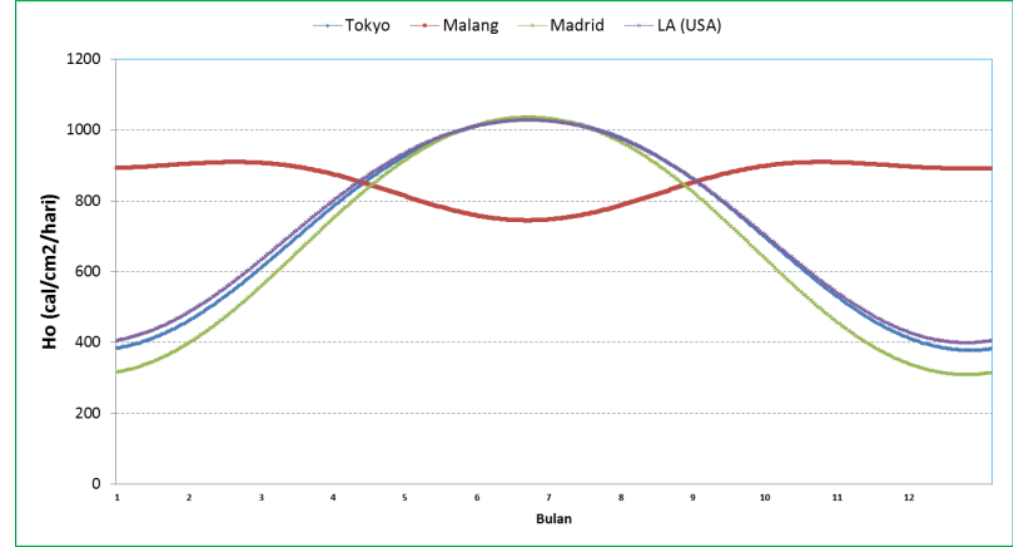

Gambar 4. Distribusi Radiasi Matahari di Puncak Atmosfer di Malang dan di berbagai Negara (BBU)

Terjadinya gerak dinamis bumi-matahari dalam setahun secara teratur tampak bahwa matahari bergerak ke utara pada bulan Juni sejauh $23,5^{\circ} \mathrm{LU}$, dan pada bulan Desember 
bergerak ke arah selatan sejauh $23,5^{\circ} \mathrm{LS}$, keadaan tersebut akan mengakibatkan terjadinya perbedaan sudut geometris matahari terhadap suatu wilayah di permukaan bumi dari waktu ke waktu atau dari bulan ke bulan. Besarnya intensitas radiasi matahari yang diterima dipermukaan bumi sangat ditentukan oleh faktor geometris, semakin besar sudut geometri bumi-matahari semakin besar radiasi yang diterima dan terasa suhu udara yang dirasakan semakin panas, demikian sebaliknya makin kecil sudut geometri bumi matahari radiasi yang diterima dipermukaan bumi semakin kecil akan dirasakan semakin tidak panas.

Pada bulan Juli hingga Agustus, posisi matahari berada di BBU. Pada saat itu penerimaan intensitas radiasi matahari cukup besar di BBU, sehingga suhu udara lebih panas pada siang hari (Gambar 4.). Benua Asia dan Eropa memiliki daratan yang lebih luas, sehingga media penyimpanan energi thermal yang berasal dari radiasi matahari sangat besar. Banyaknya industri besar yang menghasilkan gas rumah kaca dapat menahan OLR, sehingga membangkitkan osilasi gelombang panjang antara bumi dan atmofer semakin besar, hal tersebut semakin menambah suhu udara semakin terasa panas.

Terjadinya udara panas atau dingin di bumi pada saat yang sama dikendalikan oleh besarnya radiasi Ho dan besarnya Hs sebagai fungsi posisi deklinasi matahari. Radiasi matahari sebelum memasuki lapisan atmosfer bagian atas atau medium disebut radiasi Ho, sedang radiasi yang sampai dipermukaan bumi lazim disebut radiasi global (Hs).
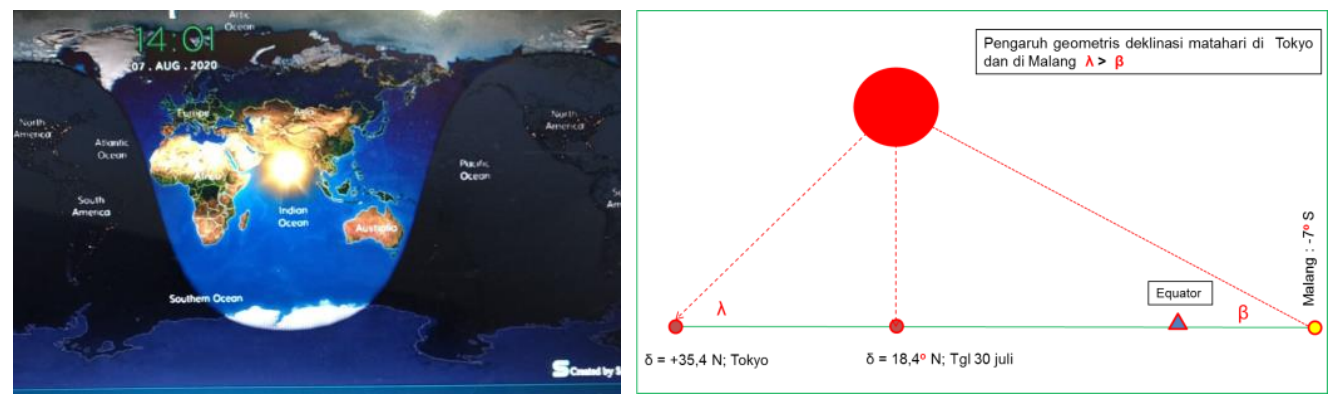

Gambar 5. Ilustrasi potongan membujur pengaruh geometris terhadap Penerimaan radiasi Matahari (Kiri) dan pengaruh geometris deklinasi matahari (Kanan)

Pada saat matahari berada di BBU yaitu antara bulan April-September intensitas radiasi matahari yang diterima di BBU relatif lebih besar dibanding di BBS (Gambar 5). Demikian juga sebaliknya pada saat matahari berada di BBS yaitu pada bulan OktoberMaret intensitas radiasi matahari di BBS relatif lebih besar bila di banding di BBU. Besarnya intensitas radiasi surya yang diterima permukaaan bumi tersebut sebanding dengan besarnya suhu yang dibangkitkan di tempat tersebut. Perubahan suhu tersebut secara berantai akan diikuti oleh besarnya perubahan unsur meteorologi lainnya.

Suhu udara panas yang terjadi Amerika Serikat, Spanyol, dan Jepang berlangsung pada bulan Juli-Agustus, keadaan tersebut berkaitan dengan posisi matahari yaitu berada di BBU. Pada saat itu penerimaan intensitas radiasi matahari cukup besar, sehingga membangkitkan suhu udara yang relatif panas pada siang hari dan berkurang di malam hari. Disamping itu negara Amerika tersebut merupakan bagian dari benua yang relatif sangat luas, sehingga media penyimpanan energi thermal yang berasal dari radiasi matahari sangat besar. Penyebab lain suhu udara semakin panas adalah banyaknya industri besar yang menghasilkan gas rumah kaca yang dapat menahan OLR, keadaan tersebut 
membangkitkan osilasi gelombang panjang antara bumi dan atmosfer yang mengakibatkan suhu terasa hangat.

Perbedaan geografi dan topografi mengakibatkan adanya adveksi udara kurang panas ke wilayah yang lebih panas sebagai fungsi jarak dan kecepatan angin. Adveksi dan osilasi udara bumi-atmosfer pada siang hari dapat membangkitan suhu udara permukaan menjadi terasa sangat panas. Sebaliknya, pada malam hari justru terjadi pelepasan radiasi gelombang panjang secara besar-besar yang berasal dari bumi. Bila kondisi langit cerah dan berada di daerah dataran tinggi akan membangkitkan suhu udara terasa semakin sangat dingin

Pada saat musim kemarau di wilayah Indonesia bagian selatan, secara teoritis terjadi adveksi udara dingin Australia ke Indonesia, terutama wilayah Jawa karena berdekatan dengan Australia dan arah angin yang menuju Indonesia. Perbedaan rentang suhu udara bulan Juli dan Januari 2020 di Australia tercatat suhu udara minimum $-9^{\circ} \mathrm{C}$ dan $-1,6^{\circ} \mathrm{C}$. Berdasarkan gambar 6., pada bulan Juli tampak bahwa makin kearah selatan (lintang tinggi) suhu semakin rendah, demikian sebaliknya pada bulan Januari hal ini menunjukkan bahwa pengaruh geometris radiasi matahari semakin nyata.
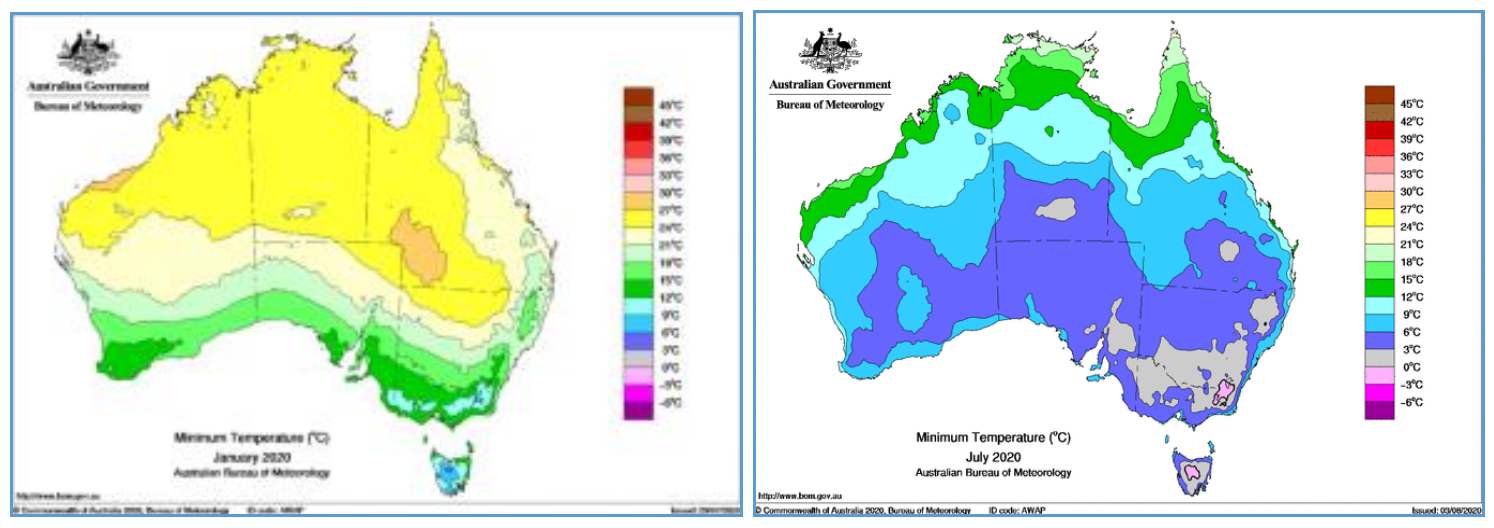

Gambar 6. Suhu udara minimum rata-rata bulan Januari (kiri), dan Juli (kanan) di Australia 2020

Untuk menguatkan analisis bahwa suhu udara dominan dikendalikan oleh posisi deklinasi matahari dari waktu ke waktu berikut disampaikan hasil analisis data meteorologi yang di rekam alat AWS stasiun klimatologi Malang tahun 2015-2020 dan data AWS tanggal 0208-2020 Stasiun Geofisika Karang Kates, Malang.

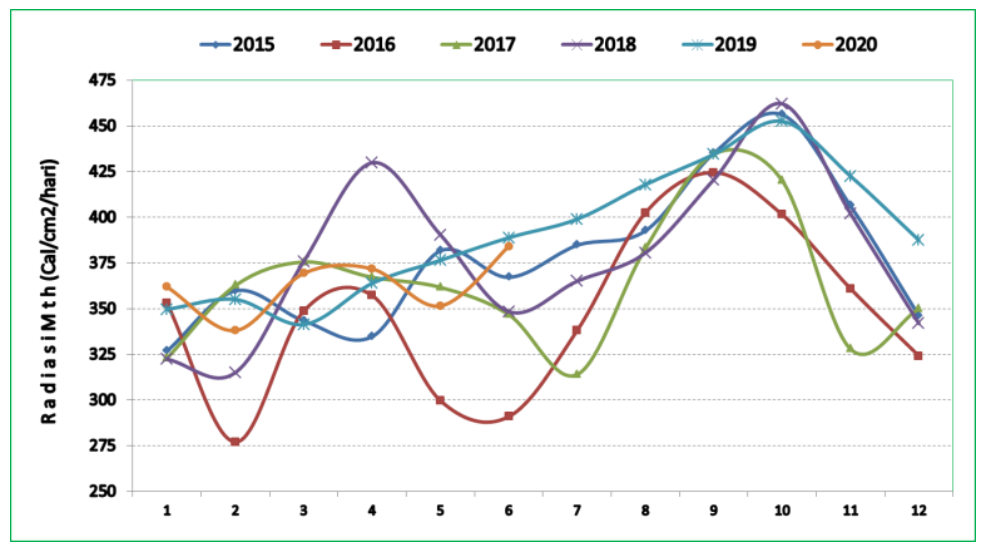

Gambar 7. Distribusi radiasi matahari global rata-rata bulanan stasiun klimatologi Malang 
Berdasarkan data radiasi global rata-rata bulanan, deklinasi matahari berada di BBS mencapai harga maksimum sekitar bulan Maret dan Oktober, namun sebaliknya pada saat Matahari berada di BBU radiasi matahari yang diterima di Stasiun Klimatologi Malang relatif berkurang, hal ini menunjukkan bahwa faktor geometris matahari terhadap stasiun sangat berperan dan faktor medium disepanjang penjalaran relatif sedikit (gambar 7).

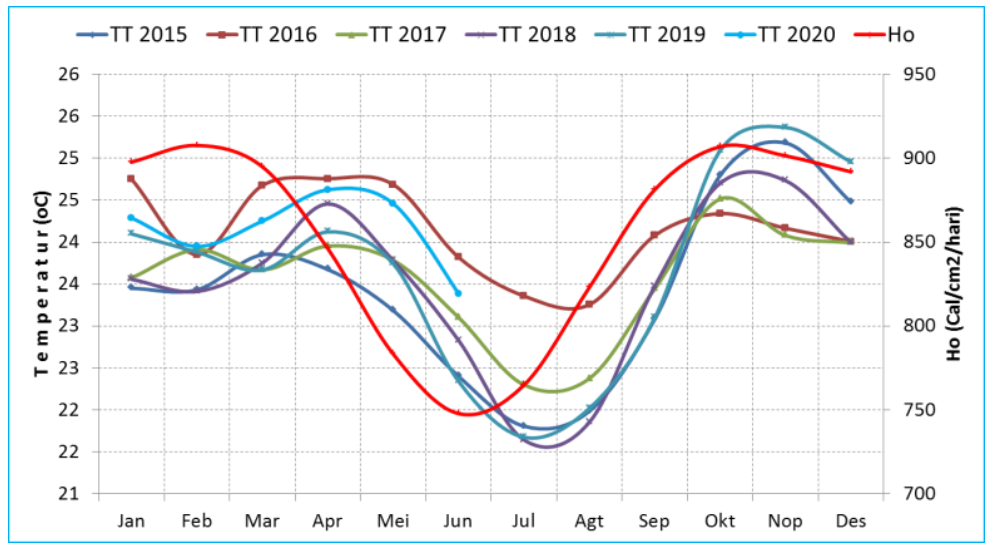

Gambar 8. Distribusi Suhu Udara rata-rata bulanan 2015-2020 dan Radiasi Puncak Atmosfer (Ho) Staklim Karang Ploso

Berdasarkan tinjauan fisis Intensitas radiasi matahari akan mempengaruhi suhu udara, hasil analisis suhu udara permukaan rata-rata bulanan Staklim Malang Jawa Timur posisi 7.54' LS, 112. 34', elevasi 600 meter menunjukkan bahwa pada musim kemarau JuniAgustus suhu relatif rendah, hal ini berkaitan dengan energi radiasi matahari yang diterima relatif kecil, karena posisi matahari berada di BBU, sebaliknya pada musim hujan Oktober-Maret suhu relatif hangat hal ini berkaitan dengan energi radiasi matahari yang diterima relatif besar karena posisi matahari berada di BBS (gambar 8).

Pada saat musim kemarau pancaran radiasi gelombang panjang yang berasal dari bumi lolos ke atmosfer dengan mudah tanpa ada penghalang karena gas rumah kaca (uap air dan gas lainnya) relatif sedikit. Untuk meyakinkan analisis tersebut berikut disampaikan deret waktu data koeffisien transmisivitas $(\mathrm{Hs} / \mathrm{Ho})$ di Stasiun klimatologi Malang (Indonesia) pada tahun 2015-2020, tampak bahwa pada musim kemarau nilainya relatif besar dibanding musim hujan. Semakin besar nilai tersebut menggambarkan besarnya radiasi yang sampai di permukaan setelah mengalami proses fisis di sepanjang medium atmosfer dan mengalami hambatan dari gas di atmosfer yang disajikan pada gambar 9 .

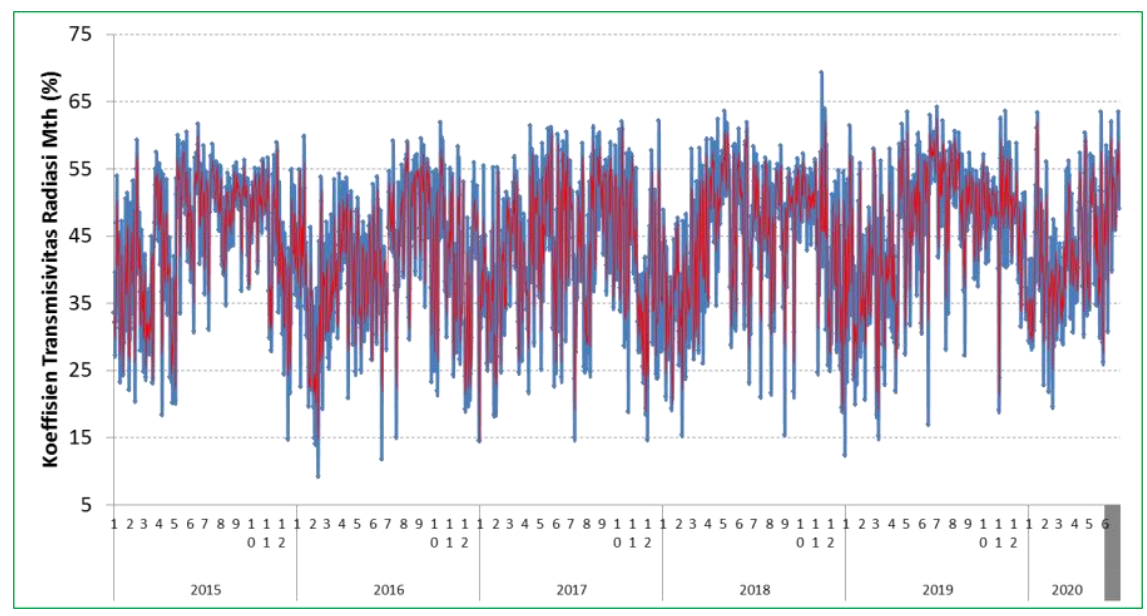

Gambar 9. Koeffisien transmisivitas radiasi matahari global harian 
Dengan menggunakan data radiasi matahari global stasiun Klimatologi Malang menunjukkan bahwa pada musim kemarau nilai transmisivitas umumnya lebih dari $50 \%$, hal ini mengindikasikan kandungan gas di atmosfer relatif sedikit, sebaliknya pada musim hujan nilainya $<50 \%$ hal ini mengindikasikan bahwa di atmosfer banyak gas $\mathrm{H} 2 \mathrm{O}$ (Gambar 9).

Informasi tinggi dasar awan (CCL) berperan sebagai lapisan osilasi radiasi gelombang panjang bumi-atmosfer yang mentriger terjadinya variasi suhu udara. Nilai CCL semakin rendah (musim hujan) akan membangkitkan suhu udara relatif hangat, sebaliknya makin tinggi (musim kemarau) akan membangkitkan suhu udara relatif dingin, terlebih untuk di daerah dataran tinggi. Analisis data CCL dan Suhu udara rata-rata stasiun Klimatologi Malang yang posisinya berada di BBS, dari data deret waktu harian selama periode 20152019 (gambar 10), tampak bahwa tinggi CCL bulan Januari lebih rendah dibanding bulan Juli dan suhu udara permukaan bulan Januari lebih panas dibanding bulan Juli. Dari kedua gambar tersebut tampak bahwa makin rendah lapisan CCL membangkitkan suhu udara relatif hangat (Januari), sebaliknya makin tinggi lapisan CCL justru membangkitkan suhu udara relatif lebih dingin (Juli).
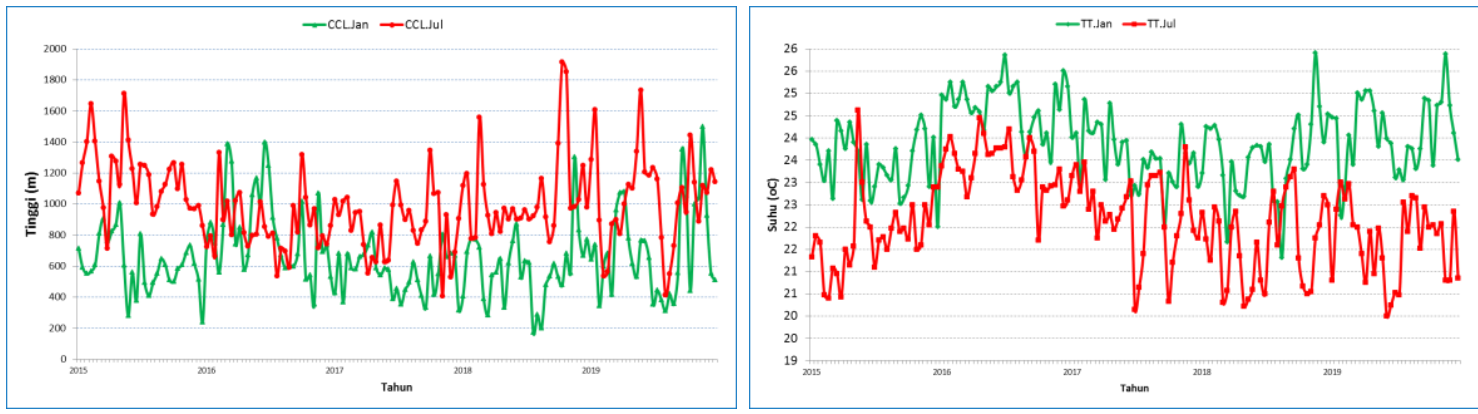

Gambar 10. Deret waktu tinggi dasar awan (kiri) dan suhu udara rata-rata harian Minimum (kanan)

Demikian juga hasil analisis data kelembapan udara pada bulan Juli relatif lebih rendah dibandingkan bulan Januari. Hal ini berkaitan berkaitan dengan selisih nilai T-Td, semakin besar selisih nilai T-Td akan membangkitkan nilai RH rendah, sebaliknya bilai T-Td kecil akan membangkitkan nilai RH besar (Gambar 11). Hasil analisis data lama penyinaran matahari yang lebih tinggi pada bulan juli, ternyata tidak membuat suhu pada bulan juli lebih tinggi. Sehingga lama penyinaran matahari tidak berpengaruh signifikan terhadap penurunan suhu pada bulan juli ini.

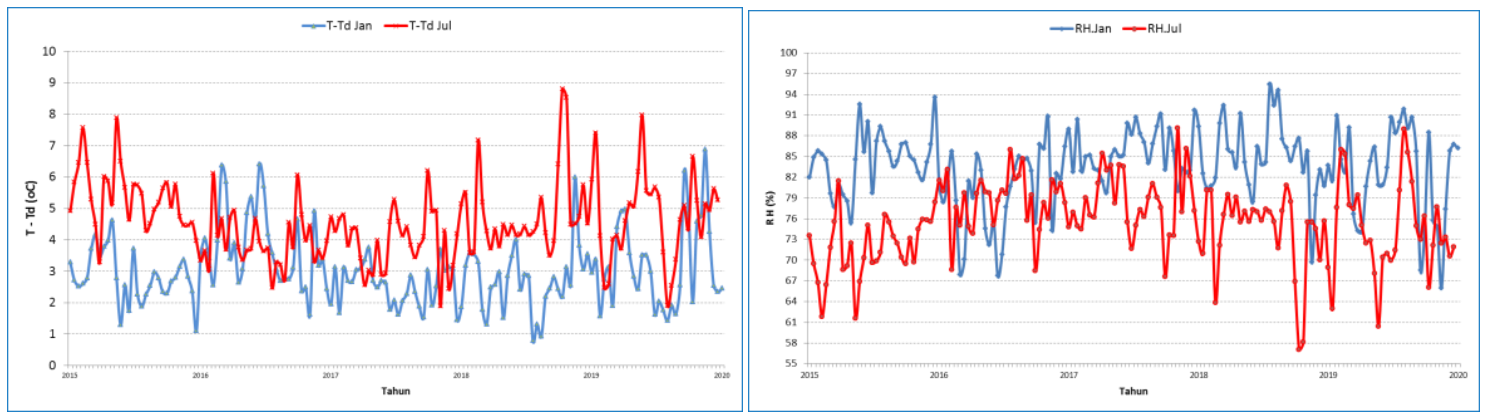

Gambar 11. Deret waktu 2015-2019 T-Td (kiri) dan Kelembapan udara (kanan) Staklim Malang

Berdasarkan tinjauan fisis pada saat suhu udara rendah (Juli) akan membangkitkan tekanan udara permukaan relatif tinggi, sebaliknya pada saat suhu udara permukaan tinggi (Januari) akan membangkitkan tekanan udara permukaan rendah. Untuk lebih jelasnya 
dapat dilihat seperti gambar 12. Hal ini menunjukkan pula, bahwa pada musim hujan di bulan januari, suhu udara Indonesia bagian selatan tercatat lebih tinggi dibandingkan musim kemarau di bulan juli.

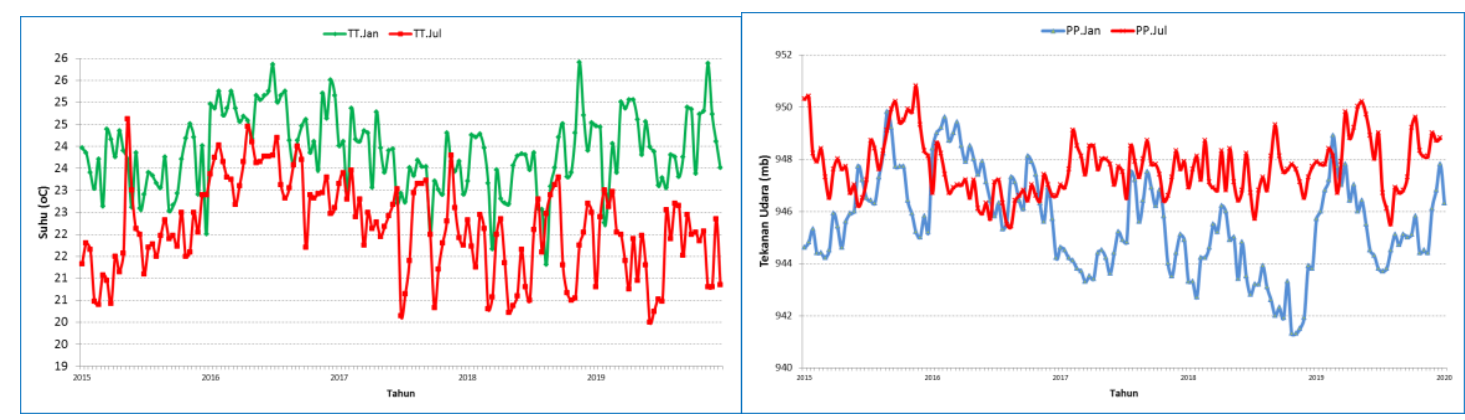

Gambar 12. Deret waktu 2015-2019 Suhu Udara (kiri) dan Tekanan udara (kanan) Staklim Malang

\section{KESIMPULAN}

Berdasarkan perhitungan dengan model lapse rate menggunakan data AWS stasiun geofisika Karangkates, diperoleh estimasi suhu udara mencapai $7,2{ }^{\circ} \mathrm{C}$ di malam hari di Ranu Pani, Lumajang. Suhu dingin pada musim kemarau di dataran tinggi Jawa Timur tersebut berkaitan dengan deklinasi matahari yang berada di BBU, sehingga radiasi matahari yang diterima pada siang hari di permukaan bumi relatif rendah dibanding bulan Januari. Penyebab lainnya yaitu tingginya koefisien transmisivitas dan adanya adveksi suhu dingin dari Australia. Pada waktu yang bersamaan, terjadinya suhu udara panas di BBU berkaitan erat dengan besarnya radiasi matahari yang diterima di wilayah tersebut, akibat pengaruh sudut geometris posisi deklinasi yang besar, dan tingginya kandungan gas rumah kaca di atmosfer yang dihasilkan dari industri. Pada saat matahari berada di utara, parameter cuaca yang mengalami kenaikan di wilayah Malang yaitu tinggi dasar awan dan tekanan udara, sedangkan parameter cuaca yang mengalami penurunan nilai yaitu suhu udara permukaan dan kelembapan udara. Parameter cuaca ini mengalami hal sebaliknya saat matahari berada di selatan.

\section{UCAPAN TERIMAKASIH}

Penulis mengucapkan terimakasih kepada Kepala Pusat Penelitian dan Pengembangan BMKG, Kepala Bidang Meteorologi Puslitbang BMKG, Stasiun Klimatologi Malang dan Stasiun Geofisika Karangkates Malang yang telah bersedia menyediakan data iklim yang dibutuhkan dalam penelitian ini.

\section{DAFTAR PUSTAKA}

1 Kautsar, M. 2019. Suhu Dieng Minus 9 Derajat Celcius, Banyak Mobil Mogok. Diakses pada 1 September 2020. Dari https://www.dream.co.id/news/suhu-dieng-anjlok-hinggaminus-9-derajat-190625i.html

2 Zain, F.M., 2020. Dataran Tinggi Dieng Diselimuti Embun Es, Suhu Udara di Bawah Nol Derajat Celsius. Diakses pada 31 Agustus 2020. Dari https://regional.kompas.com/read/2020/07/27/09422331/dataran-tinggi-diengdiselimuti-embun-es-suhu-udara-di-bawah-nol-derajat 
3 Intan, Putu. 2020. Viral di Medsos, Embun Es Muncul di Semeru. Diakses pada 1 September 2020. Dari https://travel.detik.com/travel-news/d-5118085/viral-di-medsosembun-es-muncul-di-semeru

4 Sarafil, J. 2020.Spanyol dan Inggris 'diserang' Gelombang Panas. Diakses pada 29Agustus 2020. Dari https://gempita.co/spanyol-dan-inggris-diserang-gelombangpanas/

5 --------. 2020. Suhu Udara di Jepang Mencapai 41,1 Derajat Celcius. Diakses 1 September 2020. Dari https://japanesestation.com/news/buzz-from-japan/suhu-udaradi-jepang-mencapai-411-derajat-celcius

6 ---------. 2020. NASA's ECOSTRESS Monitors California's Record-Breaking Heat Wave. Diakses pada 30 Agustus 2020. Dari https://www.jpl.nasa.gov/news/nasasecostress-monitors-californias-record-breaking-heat-wave

7 Wirawan, U.2020. Death Valley California Capai Suhu 54,4 Derajat Celcius. Diakses pada 29 Agustus 2020. Dari https://www.beritasatu.com/dunia/667107/death-valleycalifornia-capai-suhu-544-derajat-celcius

8 Matsuda, Y., Fujita, K., Ageta, Y., \& Sakai, A. 2006. Estimation of atmospheric transmissivity of solar radiation from precipitation in the Himalaya and the Tibetan Plateau. Annals of Glaciology, 43, 344-350.

9 Khatib, T., \& Elmenreich, W. 2015. A model for hourly solar radiation data generation from daily solar radiation data using a generalized regression artificial neural network. International journal of Photoenergy, 2015.

10 Mousavi Maleki, S. A., Hizam, H., \& Gomes, C. 2017. Estimation of hourly, daily and monthly global solar radiation on inclined surfaces: Models re-visited. Energies, 10(1), 134.

11 Weiskerger, C. J., Rowe, M. D., Stow, C. A., Stuart, D., \& Johengen, T. 2018. Application of the Beer-Lambert model to attenuation of photosynthetically active radiation in a shallow, eutrophic lake. Water Resources Research, 54(11), 8952-8962.

12 Pizarro, Rodrigo H.,1967. Estimation of Incoming Radiation From Extraterrestrial Radiation and Climatic Data, All Graduate Theses and Dissertations. 1607.

13 Baigorria, G. A., Villegas, E. B., Trebejo, I., Carlos, J. F., \& Quiroz, R. 2004. Atmospheric transmissivity: distribution and empirical estimation around the central Andes. International Journal of Climatology: A Journal of the Royal Meteorological Society, 24(9), 1121-1136.

14 Seidel, D. J., Ao, C. O., \& Li, K. 2010. Estimating climatological planetary boundary layer heights from radiosonde observations: Comparison of methods and uncertainty analysis. Journal of Geophysical Research: Atmospheres, 115(D16).

15 Minder, J. R., Mote, P. W., \& Lundquist, J. D. 2010. Surface temperature lapse rates over complex terrain: Lessons from the Cascade Mountains. Journal of Geophysical Research: Atmospheres, 115(D14).

16Thayyen, R. J., \& Dimri, A. P. 2018. Slope environmental lapse rate (SELR) of temperature in the monsoon regime of the western Himalaya. Frontiers in Environmental Science, 6, 42. 
17 Córdova, M., Célleri, R., Shellito, C. J., Orellana-Alvear, J., Abril, A., \& CarrilloRojas, G. 2016. Near-surface air temperature lapse rate over complex terrain in the Southern Ecuadorian Andes: implications for temperature mapping. Arctic, Antarctic, and Alpine Research, 48(4), 673-684.

18 Romps, D. M. 2017. Exact expression for the lifting condensation level. Journal of the Atmospheric Sciences, 74(12), 3891-3900.

19Daidzic, N. E. 2019. A new model for lifting condensation levels estimation. International Journal of Aviation, Aeronautics, and Aerospace, 6(5), 1. 